\title{
THE ROLE OF INDIVIDUAL AND COMMUNITY FACTORS ON THE USE OF LONG-TERM CONTRACEPTIVE METHODS (MKJP) ON WOMEN OF REPRODUCTIVE AGE COUPLES IN INDONESIA 2018
}

\author{
Vernonia Yora Saki ${ }^{1}$, Ema Novita Deniati $^{2}$, Besral $^{3}$, and Mario Ekoriano ${ }^{4}$ \\ ${ }^{1}$ Faculty of Industrial Technology, Al-Kamal Institute of Science and Technology, Jakarta, Indonesia \\ ${ }^{2}$ Faculty of Sport Sciences, State University of Malang, Malang, Indonesia \\ ${ }^{3}$ Faculty of Public Health, University of Indonesia, Depok, Indonesia \\ ${ }^{4}$ National Population and Family Planning Board, Jakarta, Indonesia \\ Corresponding address: Vernonia Yora Saki \\ Email: yorasaki1331@gmail.com
}

\begin{abstract}
This research discussed the role of individual and community factors on the use of Long Term Contraceptive Method (MKJP) in women of reproductive age couple by region in Indonesia in 2017. The study design follows the advanced analysis design of RPJMN BKKBN survey data that was cross-sectional design. The sample of research on RPJMN survey was women of reproductive age couple. Data were analyzed by Multilevel Logistic Regression analysis. The results showed that the Proportion of women of reproductive age couples using long-term contraceptive methods (MKJP) in Java Bali (27.2\%) more than high than Outside of Java Bali I (22.9\%) and Outside of Java Bali II (20.2\%). Multilevel analysis results showed that there are variations between provinces of MKJP used in women of reproductive age couple in the area of Indonesia Java Bali and Outside of Java Bali I of 1.4 and 1.3 in the area of Outside of Java Bali II. Based on the results, BKKBN recommended implementing MKJP usage program that takes into account the area aspect and cannot be uniform for all provinces in Indonesia.
\end{abstract}

Keywords: Contraception MKJP, Women WUS

\section{INTRODUCTION}

One alternative to reduce the rate of population growth that has been done in Indonesia is by implementing a Family Planning program (KB). The family planning program is the main focus of the population program in Indonesia so that families are able to plan the number of children and adjust the distance of birth according to the wishes and conditions of the family or partner without any element of coercion. Delays in pregnancy, regulation of birth spacing, and restrictions on the number of children or ending fertility can provide an opportunity for mothers to improve their physical and psychological health conditions and carry out social activities (Indonesian Republic Act
Number 52 of 2009 concerning Population Development and Family Development).

Efforts to create a quality family, the main goal was control of population growth and increase the quality of small families that are characterized by the increasing use of rational, effective, and efficient contraceptive methods (REE). Contraceptive methods that meet the effective, and efficient elements are IUD, MOW, MOP, and Implant contraceptive methods, effective for preventing pregnancy and the cost is cheaper because once a service is paid it can be used for a long time so-called long-term contraceptive method (MKJP) (Dewi, 2014).

The results of the 2017 RPJMN survey show that the prevalence of MKJP in most parts of Indonesia still has not reached the national MKJP target of $23.50 \%$ (2015- 
2019 RPJMN). From the results of the 2017 RPJMN survey of married women aged 1549 according to the contraception method used by the province, it was seen that Bali was the province with the most long-term contraceptive method (MKJP) such as IUD $(20 \%)$, DI Yogyakarta (14\%), while the lowest use of IUDs are married women in Central Kalimantan Province $(0.5 \%)$ and the provinces of North Maluku, West Papua, South Kalimantan, and Southeast Sulawesi, where the percentage was below (1\%). Other uses of MKJP such as sterilization women were dominated by married women in North Sumatra Province (9\%), then Bali (6\%) and Riau Islands (5\%). The lowest use of sterilization MKJP in women in married women in South Kalimantan was less than $(1 \%)$. Whereas the use of MKJP such as implants for KB used by married women is mostly in Gorontalo Province (20\%) and the lowest in Aceh which is only (1\%) (National Family Planning Coordinating Board, 2017).

In an effort to reduce the disparity in the use of MKJP in Indonesia, regional-based information is needed. Based on the data and description above, the researchers divided the focus of research into long-term contraceptive use (MKJP) in Indonesia by region. The division of this region refers to the 1991 IDHS which consisted of Java Bali (DKI Jakarta, West Java, Central Java, DIY, East Java, Banten and Bali), Outside of Java Bali I (Aceh, North Sumatra, West Sumatra, South Sumatra, Lampung, Bangka Belitung Islands, West Nusa Tenggara, West Kalimantan, South Kalimantan, North Sulawesi, South Sulawesi, Gorontalo and West Sulawesi) and Outside of Java Bali II (Riau, Jambi, Bengkulu, Riau Islands, East Nusa Tenggara, Central Kalimantan, East Kalimantan, North Kalimantan, Central Sulawesi, Southeast Sulawesi, Maluku, North Maluku, West Papua and Papua) (National Family Planning Coordinating Board, Central Bureau of Statistics, 1992).
The disparity in the use of MKJP in Indonesia in each region in Indonesia can be caused by various factors that can be grouped into individual, family, and community factors. According to the study by Asiimwe (2013) in Uganda, it was suggested that the use of contraception has a relationship with individual factors such as education level, wealth index, and the desire to have children (Asiimwe JB, 2013). Research by Indira \& Palarto (2009) on family factors that influence MKJP contraceptive use shows that poor families tend to choose contraception which is included in the non MKJP type. Community factors also contribute to the use of MKJP as seen from the research conducted by Ejembi et al. (2015) which found that community factors influence the use of contraception through various forms, such as socio-economic conditions, availability of health facilities, and infrastructure (Indira, L.K.T., \& Palarto, 2009).

\section{METHOD}

The design of this study was the continued analysis of the BKKBN RPJMN survey data in 2017. The BKKBN RPJMN survey uses a cross sectional study design, which is a research design used to obtain an event at a given time. Dependent and Independent variables in this study are based on the 2017 RPJMN survey questionnaire. The target population includes all women of reproductive age (15-49 years old). All members of the target population were samples of households where they normally live. The RPJMN survey was conducted in 2017 using stratified multistage cluster sample designs. Based on 2017 RPJMN survey data, the number of women of reproductive age was 52,340 people, after going through the established inclusion and exclusion criteria, there were 21,611 women of reproductive age had couples aged 15-49 in Indonesia person. The 2017 RPJMN 
survey protocol has received an ethical permit from the Research Ethics of National Population and Family Planning (BKKBN), while the study has passed the ethics of the Ethics Research and Community Health Service Commission FKM UI with number 35/UN2.F10/PPM.00.02/2018. Data was processed using the STATA 13 license program FKM UI, starting with the re-coding of each variable to fit the predetermined category. Bivariate analysis using the chisquare test with a value of $p<0.05$ was considered significant then odds ratios (OR) and $95 \%$ confidence intervals $(95 \% \mathrm{CI})$ were calculated for each categorical variable. Multilevel analysis of logistic regression models was used to determine the role of individual and community factors on the use of MKJP. After getting the final parsimony model, then a multilevel analysis approach with the first level was individual, while the contextual level is the province throughout Indonesia which is divided into three regions, namely Bali Java, Outside of Java Bali I, and Outside Java Bali II. The purpose of multilevel analysis at the contextual level in this research was to determine the variation in the use of MKJP between provinces using the Median Odds Ratio (MOR) parameter. The MOR calculation value is always $\geq 1$ (there is considerable variation between groups at the contextual level. if the value of $\mathrm{MOR}=1$, it means there is no variation between groups (Tom A. B. Snijders, 2012).

\section{RESULTS}

\section{Proportion of Using MKJP}

The 2017 RPJMN survey data, which was further analyzed in this study, found that the highest use of MKJP in Java Bali was $27.2 \%$.

Table 1. Proportion of MKJP Usage in Indonesia

\begin{tabular}{llllllc}
\multirow{2}{*}{ Variable } & \multicolumn{2}{c}{ Java Bali } & \multicolumn{2}{c}{ Outside Java Bali I } & \multicolumn{2}{c}{ Outside Java Bali II } \\
\cline { 2 - 7 } & $\mathrm{N}$ & $\%$ & $\mathrm{~N}$ & $\%$ & $\mathrm{~N}$ & $\%$ \\
\hline Non MKJP & 4284 & 72.8 & 6618 & 77.1 & 5695 & 79.8 \\
MKJP & 1604 & 27.2 & 1969 & 22.9 & 1441 & 20.2 \\
\hline Total & 5888 & 100 & 8587 & 100 & 7136 & 100 \\
\hline
\end{tabular}

Variables at the individual level consist of eight variables, namely age, education, employment, number of living children, access to information, decision making, visits by family planning officers, and source of services. By using the principle of Hierarchical Well Formulated Model (HWF), p value $(<0.05)$ and the biological plausibility, the eight variables were entered into multilevel analysis regression logistic random intercept modeling (Hosmer, D. W., Lemeshow, 2000). Modeling was done by issuing variables that have a value of $p$ value> 0.05 one by one starting with the variable with the largest $p$ value so that the fit model is obtained according to existing statistics and theories. This is done until no more variables are obtained with a value of $p>0.05$ (See Table 1). The role of individual and community factors on the use of contraceptive methods was seen through the calculation of the Median Odds Ratio at the individual and provincial levels. To see the strength of the variables, calculate the parameter odds ratio (OR) at the individual level, and the median odds ratio (MOR) at the provincial level and the magnitude of each factor. In the Java Bali region, MOR at the provincial level when the individual variables were entered into the model was 1.5. Then if 
provincial level variables (level 1 and 2) were entered into the model, the MOR value decreases to 1.4. That was, respondents living in the Java-Bali province who live in cities and medium and high wealth indices have a 1.4 times chance to use long-term contraception (MKJP) compared to rural and low wealth index respondents (See table 1). At the provincial level in the Java Bali region, the individual factors that most play a role in the use of MKJP are service sources with an $\mathrm{AOR}=7.1$. This means that women of reproductive age who get government service sources have a 7.1 chance of using MKJP compared to private service sources. Moreover, on community factors, women of reproductive age who have a high wealth index have 2.4 times the chance to use MKJP compared to women of reproductive age who have a low wealth index (see Table 2).

Table 2. Final Models Influencing the Use of MKJP in Java and Bali

\begin{tabular}{|c|c|c|c|c|c|c|}
\hline \multirow[b]{2}{*}{ Variable } & \multicolumn{3}{|c|}{ Level 1} & \multicolumn{3}{|c|}{ Level 1 and 2} \\
\hline & $\begin{array}{c}P \\
\text { value }\end{array}$ & AOR & $95 \% \mathrm{CI}$ & $\begin{array}{c}P \\
\text { value }\end{array}$ & AOR & $95 \% \mathrm{CI}$ \\
\hline \multicolumn{7}{|l|}{ Individual Level } \\
\hline \multicolumn{7}{|l|}{ Age } \\
\hline $15-24$ years & *Ref & $*$ Ref & *Ref & *Ref & *Ref & *Ref \\
\hline $25-34$ years & 0.022 & 1.5 & $1.1-2.1$ & 0.029 & 1.5 & $1.0-2.0$ \\
\hline $35-44$ years & 0.0001 & 2.2 & $1.5-3.0$ & 0.0001 & 2.1 & $1.5-2.9$ \\
\hline 45-49 years & 0.0001 & 2.8 & $1.9-4.0$ & 0.0001 & 2.7 & $1.9-3.8$ \\
\hline \multicolumn{7}{|l|}{ Educational Stage } \\
\hline Primary school and lower & $* \operatorname{Ref}$ & $*$ Ref & *Ref & $* \operatorname{Ref}$ & $* \operatorname{Ref}$ & *Ref \\
\hline Junior high school & 0.0001 & 1.5 & $1.3-1.8$ & 0.0001 & 1.5 & $1.2-1.8$ \\
\hline Senior high school & 0.0001 & 2.5 & $2.1-2.9$ & 0.0001 & 2.3 & $1.9-2.7$ \\
\hline Academy/College & 0.0001 & 5.8 & $4.5-7.3$ & 0.0001 & 5.2 & $4.1-6.7$ \\
\hline \multicolumn{7}{|l|}{ Number of Children Alive } \\
\hline 0-2 Child & $* \operatorname{Ref}$ & $*$ Ref & *Ref & $* \operatorname{Ref}$ & $* \operatorname{Ref}$ & $*$ Ref \\
\hline$>2$ Child & 0.0001 & 1.9 & $1.6-2.2$ & 0.0001 & 1.9 & $1.6-2.2$ \\
\hline \multicolumn{7}{|l|}{ Decision maker } \\
\hline Partner & *Ref & $*$ Ref & *Ref & *Ref & $*$ Ref & *Ref \\
\hline Health provider & 0.0001 & 3.1 & $1.7-5.7$ & 0.0001 & 3.2 & $1.7-5.8$ \\
\hline Acceptor and health provider & 0.013 & 1.6 & $1.1-2.4$ & 0.013 & 1.7 & $1.1-2.4$ \\
\hline Acceptor and partner & 0.137 & 1.2 & $0.9-1.7$ & 0.111 & 1.3 & $0.9-1.7$ \\
\hline Own acceptor & 0.0001 & 0.6 & $0.4-0.8$ & 0.0001 & 0.6 & $0.4-0.8$ \\
\hline \multicolumn{7}{|l|}{ Source of service } \\
\hline Private & $* \operatorname{Ref}$ & $* \operatorname{Ref}$ & *Ref & $*$ Ref & $* \operatorname{Ref}$ & $* \operatorname{Ref}$ \\
\hline Government & 0.0001 & 7.0 & $6.1-8.1$ & 0.0001 & 7.1 & $6.2-8.3$ \\
\hline \multicolumn{7}{|l|}{ Provincial Level } \\
\hline Residence (City) & & & & 0.001 & 1.3 & $1.1-1.5$ \\
\hline $\begin{array}{l}\text { Community wealth index } \\
\text { (Intermediate) }\end{array}$ & & & & 0.035 & 2.0 & $1.0-5.0$ \\
\hline $\begin{array}{l}\text { Community wealth index } \\
\text { (High) }\end{array}$ & & & & 0.044 & 2.4 & $1.0-5.4$ \\
\hline
\end{tabular}




\begin{tabular}{|c|c|c|c|c|c|c|}
\hline \multirow[b]{2}{*}{ Variable } & \multicolumn{3}{|c|}{ Level 1} & \multicolumn{3}{|c|}{ Level 1 and 2} \\
\hline & $\begin{array}{c}P \\
\text { value }\end{array}$ & AOR & $95 \% \mathrm{CI}$ & $\begin{array}{c}P \\
\text { value }\end{array}$ & AOR & $95 \% \mathrm{CI}$ \\
\hline \multicolumn{7}{|l|}{ Random Effect } \\
\hline Provincial level variance & 0.5 & & 0.4 & & & \\
\hline \multicolumn{7}{|l|}{ Inter Class Correlation } \\
\hline Provincial level & $5.9 \%$ & & $4.2 \%$ & & & \\
\hline Median Odds Ratio & 1.5 & & 1.4 & & & \\
\hline
\end{tabular}

Outside of Java Bali 1, MOR at the provincial level was 1.8 if individual variables were included into the model. Moreover, it decreased to 1.4 if provincial level variables (level 1 and 2) were entered into the model. It can be concluded that respondents who live in outside Java Bali I, live in cities, live in a medium and high wealth index, had a 1.4 times chance to use long-term contraception (MKJP) compared to respondents who live in rural areas and low wealth index (see Table 2).
In the provincial level outside Java Bali I, the individual factor that played the most role in the use of MKJP is the source of service with $\mathrm{AOR}=4.7$. This means that women of childbearing age who received government service sources had a 4.7 times chance of using MKJP compared to private service sources. On community factors, women of childbearing age living in urban areas had a 1.3 times chance to use MKJP compared to women of childbearing age living in rural areas (see Table 3).

Table 3. Final Model of AOR and MOR Influencing the Use of Contraception Methods Outside of Java Bali I Indonesia

\begin{tabular}{|c|c|c|c|c|c|c|}
\hline \multirow[b]{2}{*}{ Variable } & \multicolumn{3}{|c|}{ Level 1} & \multicolumn{3}{|c|}{ Level 1 and 2} \\
\hline & $\begin{array}{c}P \\
\text { value }\end{array}$ & AOR & $95 \% \mathrm{CI}$ & $\begin{array}{c}P \\
\text { value }\end{array}$ & AOR & $95 \% \mathrm{CI}$ \\
\hline \multicolumn{7}{|l|}{ Individual Level } \\
\hline \multicolumn{7}{|l|}{ Age } \\
\hline $15-24$ years & $*$ Ref & $* \operatorname{Ref}$ & *Ref & $* \operatorname{Ref}$ & $*$ Ref & *Ref \\
\hline $25-34$ years & 0.010 & 1.4 & $1.1-1.9$ & 0.010 & 1.4 & $1.1-1.9$ \\
\hline $35-44$ years & 0.0001 & 1.9 & $1.4-2.5$ & 0.0001 & 1.9 & $1.4-2.5$ \\
\hline $45-49$ years & 0.0001 & 2.4 & $1.8-3.2$ & 0.0001 & 2.3 & $1.7-3.2$ \\
\hline \multicolumn{7}{|l|}{ Educational Stage } \\
\hline Primary school and lower & $* \operatorname{Ref}$ & $*$ Ref & $*$ Ref & $* \operatorname{Ref}$ & $*$ Ref & *Ref \\
\hline Junior high school & 0.003 & 1.3 & $1.1-1.5$ & 0.006 & 1.2 & $1.1-1.4$ \\
\hline Senior high school & 0.0001 & 1.7 & $1.4-1.9$ & 0.0001 & 1.6 & $1.3-1.8$ \\
\hline Academy/College & 0.0001 & 3.3 & $2.7-4.1$ & 0.0001 & 3.2 & $2.6-3.9$ \\
\hline \multicolumn{7}{|l|}{ Number of Children Alive } \\
\hline 0-2 Child & *Ref & $*$ Ref & $*$ Ref & $* \operatorname{Ref}$ & $*$ Ref & $*$ Ref \\
\hline$>2$ Child & 0.0001 & 1.8 & $1.6-2.1$ & 0.0001 & 1.8 & $1.6-2.0$ \\
\hline \multicolumn{7}{|l|}{ Information Access } \\
\hline Never access & *Ref & *Ref & $*$ Ref & $* \operatorname{Ref}$ & $*$ Ref & *Ref \\
\hline Printed media & 0.587 & 0.9 & $0.7-1.2$ & 0.485 & 0.9 & $0.7-1.2$ \\
\hline Electronic media & 0.155 & 1.2 & $0.9-1.4$ & 0.205 & 1.1 & $0.9-1.4$ \\
\hline
\end{tabular}




\begin{tabular}{|c|c|c|c|c|c|c|}
\hline \multirow[b]{2}{*}{ Variable } & \multicolumn{3}{|c|}{ Level 1} & \multicolumn{3}{|c|}{ Level 1 and 2} \\
\hline & $\begin{array}{c}P \\
\text { value }\end{array}$ & AOR & $95 \% \mathrm{CI}$ & $\begin{array}{c}P \\
\text { value }\end{array}$ & AOR & $95 \% \mathrm{CI}$ \\
\hline $\begin{array}{l}\text { Printed media and electronic } \\
\text { media }\end{array}$ & 0.001 & 1.4 & $1.1-1.7$ & 0.005 & 1.3 & $1.1-1.6$ \\
\hline \multicolumn{7}{|l|}{ Decision maker } \\
\hline Partner & $* \operatorname{Ref}$ & $* \operatorname{Ref}$ & $* \operatorname{Ref}$ & $* \operatorname{Ref}$ & $* \operatorname{Ref}$ & $* \operatorname{Ref}$ \\
\hline Health provider & 0.0001 & 2.9 & $1.7-5.2$ & 0.0001 & 2.9 & $1.7-5.1$ \\
\hline Acceptor and health provider & 0.005 & 1.7 & $1.2-2.4$ & 0.004 & 1.7 & $1.2-2.4$ \\
\hline Acceptor and partner & 0.120 & 1.2 & $0.9-1.6$ & 0.085 & 1.2 & $0.9-1.6$ \\
\hline Own acceptor & 0.0001 & 0.6 & $0.5-0.8$ & 0.0001 & 0.6 & $0.5-0.8$ \\
\hline \multicolumn{7}{|l|}{$\begin{array}{l}\text { Visit of Family Planning } \\
\text { Officers }\end{array}$} \\
\hline No & $*$ Ref & $* \operatorname{Ref}$ & $*$ Ref & $* \operatorname{Ref}$ & $* \operatorname{Ref}$ & $* \operatorname{Ref}$ \\
\hline Yes & 0.003 & 0.8 & $0.7-0.9$ & 0.004 & 0.8 & $0.7-0.9$ \\
\hline \multicolumn{7}{|l|}{ Source of service } \\
\hline Private & $* \operatorname{Ref}$ & $* \operatorname{Ref}$ & $* \operatorname{Ref}$ & $* \operatorname{Ref}$ & $* \operatorname{Ref}$ & $* \operatorname{Ref}$ \\
\hline Government & 0.0001 & 4.6 & $4.1-5.2$ & 0.0001 & 4.7 & $4.1-5.3$ \\
\hline \multicolumn{7}{|l|}{ Provincial Level } \\
\hline Residence (City) & & & & 0.0001 & 1.3 & $1.1-1.4$ \\
\hline $\begin{array}{l}\text { Community wealth index } \\
\text { (Intermediate) }\end{array}$ & & & & 0.0001 & 0.3 & $0.2-0.6$ \\
\hline $\begin{array}{l}\text { Community wealth index } \\
\text { (High) }\end{array}$ & & & & 0.0001 & 0.3 & $0.2-0.6$ \\
\hline
\end{tabular}

\begin{tabular}{lcc}
\hline Random Effect & & \\
\hline Provincial level variance & 0.6 & 0.4 \\
\hline Inter Class Correlation & & \\
\hline Provincial level & $10.2 \%$ & $4.2 \%$ \\
\hline Median Odds Ratio & 1.8 & 1.4 \\
\hline
\end{tabular}

Outside of Java Bali II, MOR at the provincial level was 1.5 if the individual variables were included into the model. Moreover, it decreased to 1.3 if provincial level variables (level 1 and 2) were included into the model. It can be seen that there were variations in respondents who live in urban provinces compared to rural areas and were exposed to information by health workers rather than not exposed to long-term contraception (MKJP) (see Table 3).

At the provincial level outside Java-Bali II, the most significant individual factor in the use of MKJP was the source of service with $\mathrm{AOR}=3.5$. This can be concluded that women of childbearing age who receive government service sources were 3.5 times more likely to use MKJP compared to private service sources. Furthermore, referring to on community factors, women of childbearing age who are exposed to information by health workers had a 1.7 times chance to use MKJP compared to women of childbearing age who are not exposed to information by health workers (see Table 4). 
Table 4. Final Model of AOR and MOR Influencing the Use of Contraception Methods in Outside of Java Region II

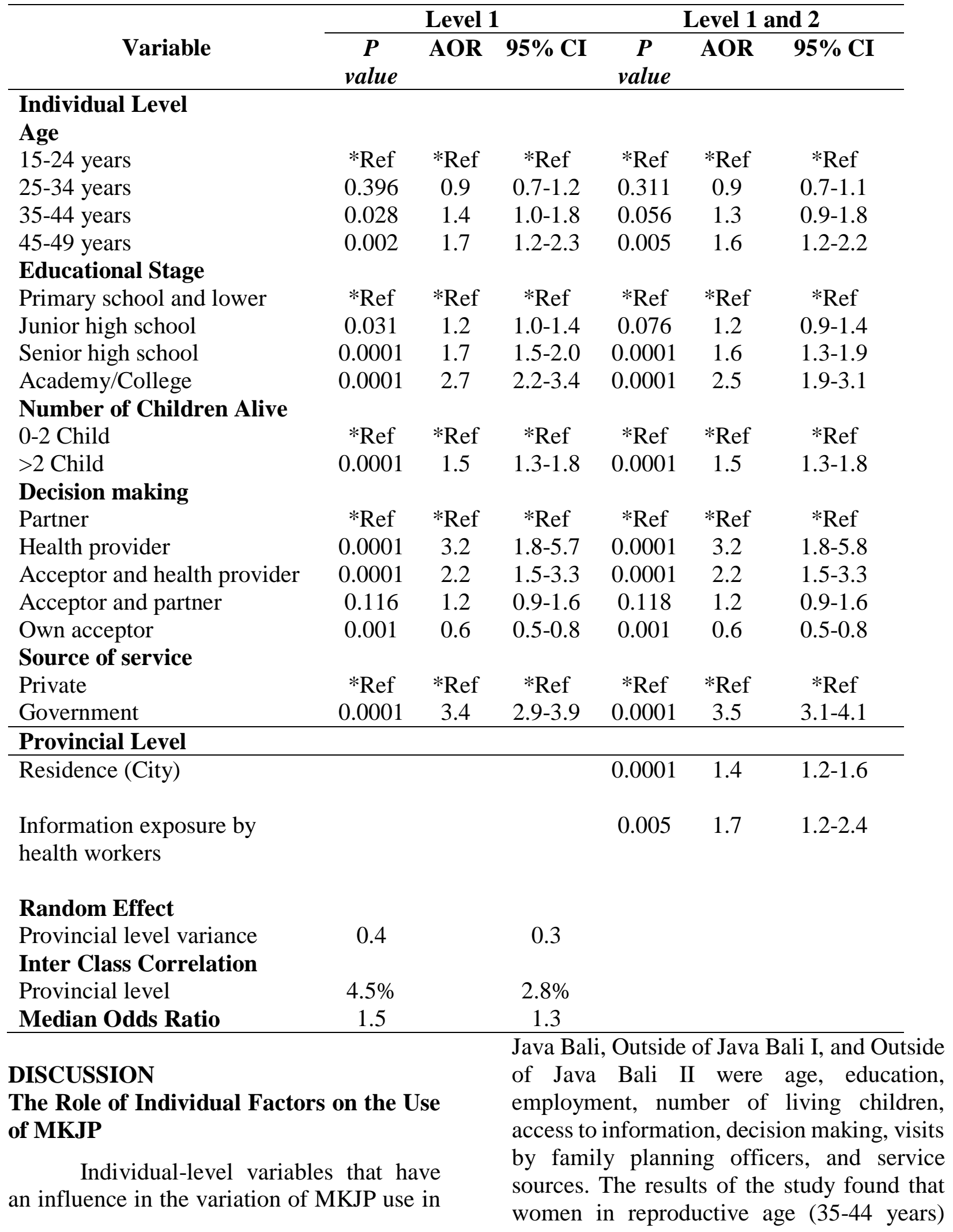


were more likely to use MKJP compared to women in reproductive age of 15-24 years. Moreover, women in reproductive age (45-49 years) had the opportunity to use MKJP compared to women of reproductive age (1524 years). This is consistent with the results of the 2007 IDHS that contraceptive needs varied according to age. Adolescent women tend to place pregnancies and older women tend to limit pregnancy. Adolescent women tend to use injection contraception, pills, and implants while those who are older tend to choose long-term contraceptives such as IUD and sterilization (National Family Planning Coordinating Board, Central Bureau of Statistics, 2008)

In the pattern of family planning and rational contraceptive use where the age below 20 years is a phase of delaying or preventing pregnancy. This is related to highrisk pregnancies which can occur at pregnancy less than 18 years old, pregnancy over 35 years, pregnancy after 4 births, and pregnancy with a distance interval of less than 2 years. In other words, high-risk pregnancies can arise in the condition of "4 too" which is too young, too old, too much and too close to the distance. At the age of 2030 years, it is the phase of spacing pregnancy and the age above 35 years is the phase of stopping / ending the pregnancy (Hartanto, 2010). The results of this study were also similar to the study conducted by Abebaw Gebeyehu (2015) in the Hossana City, Southern Ethiopia where age was substantially related to the use of contraceptive methods by couples of childbearing age at the age of 35 years due to the goal of limiting birth (Abebaw Gebeyehu, 2015).

Education has an important role in influencing contraceptive use. In some countries, women who are highly educated are more likely to use the contraceptive method than women with low education. Some levels of education also influence the variation in the use of long-term contraceptive methods, as seen from the large proportion of those using long-term contraception in the higher education group which is $32.82 \%$. High levels of education also make people aware of the effects of non MKJP contraception such as condoms and realize the benefits of using MKJP such as IUDs (Korhan, K., Goksu Goc., 2012). From the results of research and theory, it can be concluded that education plays a role in contraceptive use by women in reproductive age due to higher education. Women of fertile age couples will be more easily understood and accept contraception. They will be easier to understand the benefits. Besides that, the loss of contraception can change the mindset, thus women in reproductive age will have a positive attitude towards contraception compared to those with less education.

The study also found that the use of MKJP was highest in the group of respondents with a large number of children living (> 2 children). This finding is also consistent with the research conducted by Yusuf (2001) which stated that there is a significant relationship between the proportion of MKJP use and the group of respondents who have a higher number of living children (Yusuf., 2001). Likewise, Amiranty (2003) found a significant relationship between the number of children living and the use of MKJP. The possibility of a married woman adding children depends on the number of children she is born with. A woman may use contraception after having a certain number of children and also the age of the child she has born. A woman will use a contraceptive after having a number of children born. This will increase the risk of death in labor. In the sense that the number of children will greatly affect maternal health and can improve family standard of living to the fullest (Amiranty, 2003).

Based on the results of the study, the proportion of women of reproductive age 
who use MKJP was more likely to make decisions by health providers. Health providers or family planning providers also play a role in decision making in contraceptive use, which determines whether the family planning method chosen is the right method and in accordance with the medical eligibility criteria and the client's wishes or not. The approach when counseling from family planning providers to prospective acceptors through providing information, comparing multiple choices and evaluating the preferences of prospective acceptors, is very helpful for clients in joint decision making on contraceptive use (George, T. P., Decristofaro, C., Dumas, B. P., \& Murphy, 2015).

The large proportion of women in reproductive age couples who use long-term contraception from government service sources can be due to the post-birth control family planning program and the financing of post-natal care integrated with Health Insurance $(\mathrm{JKN})$. Through this program, women in reproductive age since pregnancy were introduced to family planning to prevent delay in getting them. Hopefully, these programs that are integrated with family planning services in health facilities can encourage women in reproductive age to choose and use contraception because of the amount of information absorbed by women in reproductive age through activities in health facilities (National Family Planning Coordinating Board, Central Bureau of Statistics, 2013).

\section{The Role of Community Factors on the Use of MKJP}

This study found that there were variations in residence with the use of longterm contraceptive methods (MKJP) in the Java Bali, Outside of Java Bali I, and Outside of Java Bali II. This is also related to disparities between residential areas. In accordance with the 2013 Riskesdas data, it was found that MKJP use was higher in women living in urban areas compared to rural areas (National Institute of Health Research and Development, 2013).

Based on Ethiopian DHS data, it was also found that the prevalence of contraceptive use was higher in urban areas than in rural areas. This difference is due to variations in rural and urban areas, where in rural areas most women have low education, low socioeconomic level, and low involvement in decision making on their health care which in this case related to the use of MKJP (Eshete and Adissu, 2017).

The wealth index also plays a role in the use of MKJP in Java Bali and Outside of Java Bali I. This variation can occur because in the Java Bali region most people have a high wealth index compared to the Outside of Java Bali I. In accordance with the research conducted by Ejembi, Clara Ladi, Tukur Dahiru, Alhaji A. Aliyu (2015), that the community with medium and high wealth index, has a ratio of 1.2 times and 1.7 times to use the long-term contraceptive method (MKJP) (Ayaga A. Bawah, James F. Phillips, 2005).

Information exposure by health workers also played a role in communitylevel contraceptive use in the Outside of Java Bali II. Gordon's research, Charlie et al (2011) showed that information exposure by health workers in Ethiopia plays a role in contraceptive use in women in reproductive age and also influenced by the desire to have children (Gordon et al., 2011). Another study conducted by Munshi and Myaux (2006) stated that households in an area and getting visits from health workers every two weeks are useful for women of reproductive age to discuss their opinions about contraceptive use. Health worker visits will be more effective in changing perceptions of women of reproductive age by delivering information through programs at the social community 
level compared to individual levels in Bangladesh (Munshi and Myaux, 2006).

One disadvantage of the direct relationship between contraceptive use and variables at the provincial level in complete modelling is the explanation at each level which should be explained more based on new and innovative theories (Kaggwa, Diop and Storey, 2008). This study found that variations between clusters were greater than contextual variations indicating that the community environment had a role for women in planning family planning and using contraceptive methods specifically MKJP. Therefore, further research is needed on community factors by using contraceptive methods at every level.

\section{CONCLUSION}

Proportion of women in reproductive age couples using long-term contraceptive methods (MKJP) in Java Bali (27.2\%) was higher than Outside of Java Bali I (22.9\%) and Outside of Java Bali II (20.2\%). The results showed that the proportion of women in reproductive age who used long-term contraceptive method in the Indonesian region of Java and Bali was the highest at $27.2 \%$. The results of multilevel analysis showed that there were variations between provinces using MKJP in women in reproductive age in the Indonesian region of Bali, Java, and Outside Java which was Bali I 1.4 and the Outside Java region of Bali II 1.3. It is recommended to $\mathrm{BKKBN}$ to conduct the MKJP use program that pays attention to regional aspects and cannot be uniformed for all provinces in Indonesia. Moreover, BKKBN multiplies print text and electronic media hence women in reproductive age have access to MKJP information.

\section{REFERENCES}

Abebaw Gebeyehu, A.E., 2015.
Determinants of Long Acting and Permanent Contraceptive Methods Utilization among Married Women in Hossana Town, Southern Ethiopia: A Case - Control Study. Journal of Pregnancy and Child Health. https://doi.org/10.4172/2376-

127X.1000165

Amiranty, M., 2003. Faktor-faktor yang berhubungan dengan Pemakaian Metode Kontrasepsi Jangka Pada Akseptor KB di Propinsi Maluku dan Papua pada Tahun 2001 (Analisis Data Sekunder Sosial Ekonomi Nasional 2001). Universitas Indonesia.

Ayaga A. Bawah, James F. Phillips, G.W., 2005. Does Women's Relative Income Predict Contraceptive use in Ghana? An Assessment Using Bargaining Theory. International Union for Scientific Study of Population.

Dewi, N., 2014. Rendahnya Keikutsertaan Pengguna Metode Kontrasepsi Jangka Panjang. Universitas Airlangga.

Eshete, A. and Adissu, Y., 2017. Women's Joint Decision on Contraceptive Use in Gedeo Zone, Southern Ethiopia: A Community Based Comparative Cross-Sectional Study. International Journal of Family Medicine, 2017, pp.1-9. https://doi.org/10.1155/2017/938907 2

George, T. P., Decristofaro, C., Dumas, B. P., \& Murphy, P.F., 2015. Shared Decision Aids: Increasing Patient Acceptance of Long-Acting Reversible Contraception. [online] pp.205-218. Available at: https://doi.org/10.3390/healthcare30 20205.

Gordon, C., Sabates, R., Bond, R. and Wubshet, T., 2011. Women's 
Education and Modern Contraceptive Use in Ethiopia. International Journal of Education, 3(1), p.9. https://doi.org/10.5296/ije.v3i1.622

Hartanto, H., 2010. Keluarga Berencana dan Kontrasepsi. Jakarta: Pustaka Sinar Harapan.

Hosmer, D. W., Lemeshow, S., 2000. Applied Logistic Regression. https://doi.org/10.1002/0471722146

Indira, L.K.T., \& Palarto, B., 2009. FaktorFaktor yang Mempengaruhi Pemilihan Jenis Kontrasepsi yang Digunakan pada Keluarga Miskin.

Indonesian Republic Act Number 52 of 2009 concerning Population Development and Family Development.

Kaggwa, E.B., Diop, N. and Storey, J.D., 2008. The role of individual and community normative factors: A multilevel analysis of contraceptive use among women in union in Mali. International Family Planning Perspectives, 34(2), pp.79-88. https://doi.org/10.1363/3407908

Korhan, K., Goksu Goc., S.T., 2012. Factors Influencing the Contraceptive Method Choice: a University Hospital Experience. Journal of Turkish German Gynecological Association.

Munshi, K. and Myaux, J., 2006. Social norms and the fertility transition. Journal of Development Economics, 80(1), pp. $1-38$. https://doi.org/10.1016/j.jdeveco.200 5.01 .002

National Family Planning Coordinating Board, 2017. Survei Indikator Kinerja Program Kependudukan Keluarga Berencana dan Pembangunan Keluarga (KKBK) Rencana Pembangunan Jangka Menengah (RPJMN). Jakarta.

National Family Planning Coordinating Board, Central Bureau of Statistics,
M. of H., 1992. Survei Demografi Dan Kependudukan Indonesia 1991. Jakarta.

National Family Planning Coordinating Board, Central Bureau of Statistics, M. of H., 2008. Survei Demografi Dan Kependudukan Indonesia 2007. Jakarta.

National Family Planning Coordinating Board, Central Bureau of Statistics, M. of H., 2013. Survei Demografi Dan Kependudukan Indonesia 2012. Jakarta.

National Institute of Health Research and Development, I.M. of H., 2013. Riset Kesehatan dasar.

Tom A. B. Snijders, 2012. Multilevel Analysis. https://doi.org/10.1007/978-3-64204898-2_387

Yusuf., A., 2001. Faktor-faktor yang Berhubungan dengan Penggunaan Metode Kontrasepsi Jangka Panjang (MKJP) di Kecamatan Tanjung Batu Kabupaten Ogan Komering Ilir Sumatera Selatan Tahun 2000. Universitas Indonesia. 